\title{
Analysis of Determinants of Village-City Migration and Economic Growth Between Provinces in Indonesia
}

\author{
Desy Anita ${ }^{1 *}$, Sri Ulfa Sentosa ${ }^{2}$ \\ 1, 2 Universitas Negeri Padang, Padang, Indonesia \\ *Corresponding author. Email: desyanita25@gmail.com
}

\begin{abstract}
This study aims to explain the relationship between rural-urban migration and economic growth, further explaining the effect of regional minimum wages on rural-urban migration, labor force participation rates on rural-urban migration, government spending on economic growth, and human capital on economic growth. between provinces in Indonesia. The data used are panel data (cross section and time series) consisting of 34 provinces in Indonesia during the 2015 to 2018 period, the method used is the 2SLS (two stages least square) simultaneous equation model. The results of the study found that economic growth, regional minimum wages, and labor force participation rates have a positive and significant effect on rural-urban migration, then government spending, human capital, and rural-urban migration have a positive and significant impact on economic growth between provinces in Indonesia.
\end{abstract}

Keywords: Rural, Urban migration, Economic growth, Two stages least square.

\section{INTRODUCTION}

Rural-urban migration is an indication of a change in community groups from low-income residents to middle-income groups. If the Village-City Migration is properly managed, it will encourage the economic growth of a country and reduce the poverty gap.

The economy is an economic activity that cannot be separated from human life anywhere in the world. And in its development the economy undergoes transformation, modernization and even innovation in its application. And of course, based on existing economic theory or basis. However, in practice economic theories are flexible according to the needs of a country or the scope of application. Because of its changes, the general changes in the economy that a country experiences are often the subject of discussion, both among scientists, economists, government officials, and people who are interested in observing the economy.

According to [1] in the macro analysis of measurements in a country's economy, namely the Gross Domestic Product (GDP). Gross Domestic Product measures the flow of income and expenditure in the economy over a certain period. Economic growth is related to the process of increasing the production of goods and services in people's economic activities. To measure economic growth, the value of GDP used is GDP which is based on constant prices (real GDP).
Rural-Urban Migration refers to the movement of rural people to urban centers in search of better jobs. Rural-Urban migration and growth go hand in hand; no country has ever achieved middle income status without significant population displacement to cities. Rural-Urban migration has a strong relationship with unemployment, economic growth. The increase in unemployment is likely to hamper Rural-Urban Migration. While employment opportunities tend to fall in urban centers, rural people see no incentive to migrate to urban areas [2].

The relationship between Rural-Urban Migration and economic growth has been a source of great concern. At one time it was the view that greater RuralUrban Migration inevitably leads to economic disease rather than economic growth. This is based on the argument that government policies are often biased in favor of urban areas at the expense of rural areas which have encouraged Rural-Urban Migration and thereby increased the size of urban areas. While this can temporarily promote economic growth in poorer countries, it will not result in the long-term equitable development that is only possible through agricultural assistance [3]. To see the development of rural - urban migration, see Figure 1. 


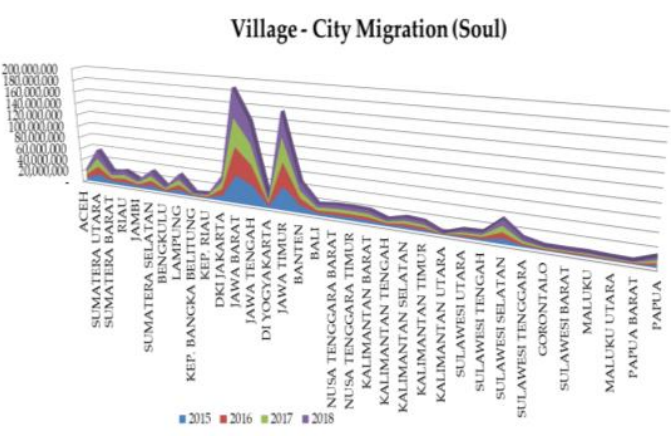

Source: West Sumatra Central Statistics Agency

Figure 1. Development of Village - City Migration between Provinces in Indonesia in 2015 - 2018

Based on Figure 1. It can be seen that the development of rural-urban migration between provinces in Indonesia varies widely, rural - urban migration generally occurs on the island of Java, the highest province of rural - urban migration is West Java Province, where West Java Province is also a province. which has a large population compared to other provinces. The province with the lowest rural-urban migration is in the province of West Papua, among other provinces, the province of West Papua is not a favorite for people to move to the province. Furthermore, to see the development of economic growth between provinces in Indonesia can be seen in Figure 2.

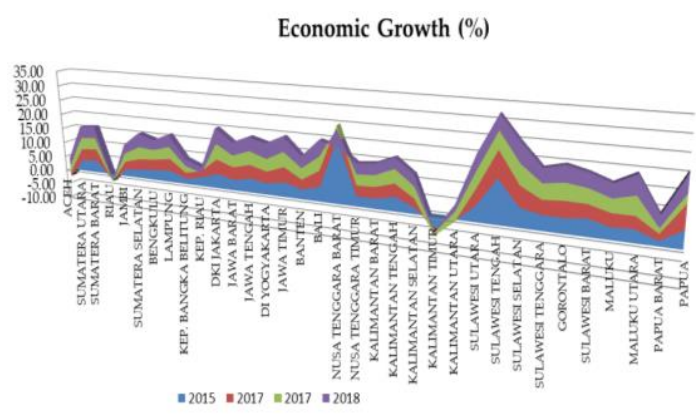

Source: West Sumatra Central Statistics Agency

Figure 2. Development of Economic Growth between Provinces in Indonesia in 2015 - 2018

Based on Figure 2, it can be seen that the development of economic growth between provinces in Indonesia fluctuates from 2015 to 2018 . The highest economic growth is in Central Sulawesi province, economic development in this province is very fast, and the lowest economic growth is in East Kalimantan province, Kalimantan province. east economic growth is often at a minus. One of the phenomena contained in Figures 1 and 2, which occurs in the province of West Nusa Tenggara, where rural-urban migration always increases from 2015 to 2018, but the economic growth of West Nusa Tenggara province has decreased economic growth every year. Based on this phenomenon, there are the mismatch of economic growth and migration with research [4] that economic growth and rural-urban migration are positively related.

\subsection{Economic Growth}

Economic growth is a process of change in economic conditions of a country that is continuous toward a better state for a certain period. Economic growth can also be interpreted as a process of increasing the production capacity of an economy which is manifested in the form of an increase in national income. Economic growth shows the growth in the production of goods and services in an economic area within a certain period of time [5]. According to [6] Economic growth is the addition of gross domestic product (GDP) which also means an increase in national income. Economic growth and rural-urban migration or urbanization are interconnected with each other [7], [8], and [9].

\subsection{Rural Urban Migration}

Rural-urban migration is a response to variations in the environmental conditions in which they live. Changing natural conditions, changes in social life, fluctuations in economic conditions and population development, through the process of the life cycle, have resulted in population mobility from one place to another [10]. Rural-urban migration or urbanization has a positive relationship with economic growth [11], [12], [13] and [14].

\subsection{Provincial Minimum Wage}

The determination of the minimum wage aims to increase the wages of workers who still earn below the minimum wage. However, the minimum wage policy not only affects the wages of workers with wage levels around the minimum wage, but also affects the entire wage distribution. Therefore, the minimum wage policy will ultimately have an impact on prices, the business climate and employment. The determination of the minimum wage still faces many obstacles, namely the mechanism for determining the minimum wage is ad $h o c$ and uncertain and the increase in the minimum wage is difficult to predict and calculate. The policy of increasing the UMP should be placed in a comprehensive and not partial industrial policy framework and macro policy framework [15].

According to [16], the elasticity of labor supply is very high in response to wage increases. Wages generally exceed the minimum level of living. Wages are paid out of capital, therefore wages are limited by the existing capital reserves that are prepared to pay wages. So the wage per head can be calculated by dividing the total rotating capital by the working population.

\subsection{Labor Force Participation Rate}

The labor force participation rate itself is an employment indicator that provides an overview of the 
population who is economically active in their daily activities, referring to a time during the survey period. The greater the number of people who are classified as non-labor force, the smaller the number of the workforce which results in the smaller the TPAK [17].

\subsection{Government Expenditure}

Government spending is part of fiscal policy, namely a government action to regulate the running of the economy by determining the amount of government revenue and expenditure each year, which is reflected in the National State Budget (APBN) document and the Regional Budget (APBD) for regions or regional. The purpose of this fiscal policy is to stabilize prices, the level of output, and job opportunities and to spur or encourage economic growth [18]. Government spending has a positive influence on economic growth [19], and [20].

\subsection{Education and Health (Human Capital)}

Education and health is human capital, according to the World Bank 2019, working man consists of knowledge, skills, and collected human health throughout their lives, which enables them to know their potential as productive members of society.

Education is the sum of the average length of schooling (RLS) using a new method in the human development index plus the expected length of school (HLS) using a new method in the human development index divided by two by units of years. Furthermore, Health uses life expectancy at birth ( $\mathrm{AHH}$ ) with a new method in the human development index, $\mathrm{AHH}$ is the estimated average number of years that a person can take from birth in units of years. Education and health have a positive effect on economic growth [21] , [22], [23], [23], [24], and [25]

\section{METHOD}

This research is classified as descriptive and associative research, because the author will describe and analyze a close relationship about the influence of one variable on another or exogenous variables on endogenous variables. This study uses a model which considers a two-way relationship as well as an indirect relationship between one variable and another. This happens if in the case of variable $\mathrm{Y}$ is influenced by variable $X$, and in other cases variable $X$ is influenced by variable $\mathrm{Y}$. In this model, there will be more than one equation, each of which is called mutually or jointly dependent/ endogenous variable. If the parameters in the equation are estimated using OLS (Ordinary Least Square), the potential results obtained will not only be biased, but also inconsistent, namely by increasing the number of samples that are getting bigger, the estimation results do not lead to the actual (population) value.

The OLS method cannot be applied to estimate an equation that has a relationship in a simultaneous equation system. If there are independent variables that have a correlation with disturbance, it will result in the estimator being inconsistent.

This simultaneous model equation where there is more than one dependent variable (dependent variable) and more than one equation. One of the unique features of simultaneous equations is that the dependent variable in one equation may appear as an explanatory variable in other variables of the system. Therefore, the variable describing the dependent becomes the stockiest and usually correlates with the disturbance of the equation in which it appears as the explanatory variable.

In the simultaneous model, there are two variables, namely endogenous variables and exogenous variables. Endogenous variables are variables whose values are set or determined by the model as a result of the relationship between variables, while exogenous variables are variables whose values are set outside the model.

The structural similarities in this study are as follows:

$\mathrm{Y}_{1}=\alpha_{0}+\alpha_{1} \mathrm{Y}_{2}+\alpha_{2} \mathrm{X}_{1}+\alpha_{3} \mathrm{X}_{2}+\varepsilon_{1 \mathrm{t}}$

$\mathrm{Y}_{2}=\beta_{0}+\beta_{1} \mathrm{Y}_{1}+\beta_{2} \mathrm{X}_{3}+\beta_{3} \mathrm{X}_{4}+\beta_{4} \mathrm{X}_{5}+\varepsilon_{2 \mathrm{t}}$

Where:

$\mathrm{Y}_{1}=$ Rural-Urban Migration

$\mathrm{Y}_{2}=$ Economic Growth

$\mathrm{X}_{1}=$ Indonesian Provincial Minimum Wage (UMP)

$\mathrm{X}_{2}=$ Labor Force Participation Rate (TPAK)

$\mathrm{X}_{3}=$ Government Expenditure

$\mathrm{X}_{4}=$ Education

$\mathrm{X}_{5}=$ Health

a. Identification Test

While the identification test with the order condition in this study is as follows:

Equation 1: $\mathrm{Kk}=5-2>\mathrm{m}-1=2-1$

$3=1 \rightarrow($ over identified $)$

Equation 2: $\mathrm{Kk}=5-3>\mathrm{m}-1=2-1$

$2=1 \rightarrow($ over identified $)$

From the results of the identification test using the order condition for the two equations above, it can be concluded that the 2 equations that are exactly identified, so to estimate the parameters of the existing equation is using the Two Stage Least Squared (TSLS) method, so the coefficient estimation is still not would be biased as this is an advantage of the Two Stage Least Squared model.

Two Stage Least Squared is an estimate that is carried out in two stages using OLS, which of course with certain rules. The first stage, estimate the parameters using OLS between endogenous variables and all exogenous variables. Thus, we will get the 
estimated endogenous variable values. The second stage, re-estimate the parameters using OLS, which now includes endogenous variables, but these variables are replaced with endogenous variables as estimated results.

\section{b. Reduce Form}

After conducting an identification test with order conditions, the next step is to carry out the reduce form process from each of the equations above. The reduce form process is carried out to determine the exogenous (predetermine) variable in the simultaneous equation system. The reduce form process from each of the equations above is as follows:

$\mathrm{Y}_{1}=\Pi_{1}+\Pi_{2} \mathrm{X}_{1}+\Pi_{3} \mathrm{X}_{2}+\Pi_{4} \mathrm{X}_{3}+\Pi_{5} \mathrm{X}_{4}+$

$\Pi_{6} \mathrm{X}_{5}+\mathrm{v}_{1}$

From the rural-urban migration equation above, it can be seen that the exogenous variables (predetermine) are the Indonesian Provincial Minimum Wage, Labor Force Participation Rate, Government Expenditure, Education, and Health.

$\mathrm{Y}_{2}=\Pi_{7}+\Pi_{8} \mathrm{X}_{1}+\Pi_{9} \mathrm{X}_{2}+\Pi_{10} \mathrm{X}_{3}+\Pi_{9} \mathrm{X}_{4}+$

$\Pi_{9} \mathrm{X}_{5}+\mathrm{v}_{2}$

From the economic growth equation above, it can be seen that the exogenous variables (predetermine) are the Indonesian Provincial Minimum Wage, Labor Force Participation Rate, Government Expenditure, Education, and Health.

\section{RESULTS AND DISCUSSION}

Heteroscedasticity Test

To detect heteroscedasticity disorders in the estimation model, a heteroscedasticity diagnostic residual test is carried out provided that if the probability value of the independent variable used is below a significant value at $\alpha=0.05$, it means heteroscedasticity occurs.

Table 1. Results of the Heteroscedasticity of the Village-City Migration Equation

Dependent Variable: RESABS

Method: Least Squares Panel

Date: 10/14/20 Time: 12:39

Sample: 20152018

Periods included: 4

Cross-sections included: 34

Total panel (balanced) observations: 136

\begin{tabular}{ccccc}
\hline \hline & & & & \\
Variable & Coefficient & Std. Error & t-Statistic & Prob. \\
\hline \hline & & & & \\
C & 5.852027 & 3.211980 & 1.821938 & 0.0707 \\
X1 & $-1.73 \mathrm{E}-07$ & $3.58 \mathrm{E}-07$ & -0.483911 & 0.6292
\end{tabular}

$\begin{array}{lllll}\mathrm{X} 2 & -0.059393 & 0.045594 & -1.302654 & 0.1949\end{array}$

Source: E-views 10 (2020, processed)

Based on Table 1. The equation of rural-urban migration can be seen that there is no independent variable whose probability value is below the significant value $\alpha=0.05$, it can be concluded that there is no heteroscedasticity.

Table 2. Results of the Heteroscedasticity Test for the Economic Growth Equation databases

Dependent Variable: RESABS

Method: Least Squares Panel

Date: 10/14/20 Time: 12:39

Sample: 20152018

Periods included: 4

Cross-sections included: 34

Total panel (balanced) observations: 136

\begin{tabular}{ccccc}
\hline \hline & & & & \\
Variable & Coefficient & Std. Error & t-Statistic & Prob. \\
\hline \hline & & & & \\
C & 2.757192 & 5,000540 & 0.551379 & 0.5823 \\
X3 & $-1.17 \mathrm{E}-08$ & $1.55 \mathrm{E}-08$ & -0.755266 & 0.4514 \\
X4 & 0.048537 & 0.164229 & 0.295543 & 0.7680 \\
X5 & -0.026785 & 0.079220 & -0.338110 & 0.7358 \\
& & & & \\
\hline \hline
\end{tabular}

Source: E-views 10 (2020, processed)

Based on table 2. The economic growth equation can be seen that there are no independent variables whose probability value is below the significant value $\alpha=0.05$, it can be concluded that there is no heteroscedasticity.

Two Stages Least Square Model

Two Stage Least Squared is an estimate that is carried out in two stages using OLS, of course with certain rules. Two stage Least Square model estimates can be seen in Table 3 and Table 4

Table 3. Test Results for the Two Stages Least Square Model of the Village-City Migration Equation

Dependent Variable: Y1

Method: Panel Two-Stage Least Squares

Date: 10/14/20 Time: 12:04 pm

Sample: 20152018

Periods included: 4

Cross-sections included: 34

Total panel (balanced) observations: 136 
Instrument specification: C X1 X2 X3 X4 X5

Constant added to the instrument list

\begin{tabular}{ccccc}
\hline \hline & & & & \\
Variable & Coefficient & Std. Error & t-Statistic & Prob. \\
\hline \hline & & & & \\
C & 72336698 & 23709586 & 3.050947 & 0.0028 \\
Y2 & 4622586. & 2022247. & 2.285866 & 0.0239 \\
X1 & 5.427585 & 2.705486 & -2.006141 & 0.0469 \\
X2 & 1046733. & 388225.0 & -2.696201 & 0.0079
\end{tabular}

Source: E-views 10 (2019, processed)

Based on Table 3, it can be written that the estimation model of this study is as follows:

$(\mathrm{Y} 1)=72336698+4622586(\mathrm{Y} 2)+5.427585(\mathrm{X} 1)+10467$

$33(\mathrm{X} 2)+\mu_{1}$

From equation (5) it can be seen that:

1. Economic growth (Y2) has a positive and significant effect on rural-urban migration (Y1) with a regression coefficient of 4622586 This means that when there is an increase in economic growth (Y2) of 1 unit, it will increase rural-urban migration (Y1) of 4622586 units.

2. Indonesia's Provincial Minimum Wage (UMP) (X1) has a positive and significant effect on rural-urban migration (Y1) with a regression coefficient of 5.427585. This means that when there is increase in the Provincial Minimum Wage (UMP) Indonesia (X1) of 1 unit it will be me raise migration village - city (Y1) of 0.326782 units.

3. The Labor Force Participation Rate (X2) has a positive and significant effect on rural-urban migration(Y1) with a regression coefficient of 1046733.This means that when the Labor Force Participation Rate (X2) is 1 unit, will increase rural urban migration (Y1) by 1046733 units.

Table 4. Test Results Model Two Stages Least Square Equation Economic Growth

Dependent Variable: Y2

Method: Panel Two-Stage Least Squares

Date: 10/14/20 Time: $12: 12$

Sample: 20152018

Periods included: 4

Cross-sections included: 34

Total panel (balanced) observations: 136

Instrument specification: C X1 X2 X3 X4 X5

Constant added to the instrument list

Variable Coefficient Std. Error t-Statistic Prob.

$\begin{array}{lllll}\mathrm{C} & 20.76394 & 6.706033 & 3.096307 & 0.0024 \\ \mathrm{Y} 1 & 3.50 \mathrm{E}-08 & 4.87 \mathrm{E}-08 & 0.718751 & 0.0436 \\ \mathrm{X} 3 & 1.74 \mathrm{E}-08 & 2.98 \mathrm{E}-08 & 0.5823890 .0103 \\ \mathrm{X} 4 & 0.083335 & 0.273292 & -0.304930 & 00409 \\ \mathrm{X} 5 & 0.234740 & 0.124517 & -1.885205 & 0.0216\end{array}$

Source: E-views 10 (2019, processed)

Based on Table 3, it can be written that the estimation model of this study is as follows:

$(\mathrm{Y} 2)=20.76394+3.50 \mathrm{E} 08(\mathrm{Y} 1)+1.74 \mathrm{E} 08(\mathrm{X} 3)+0.083335$

$(\mathrm{X} 4)+0.234740(\mathrm{X} 5)+\mu_{1}$

From equation (5) it can be seen that:

1. Rural-urban migration (Y1) has a positive and significant effect on economic growth (Y2) with a regression coefficient of 3.50E-08 This means that when there is an increase in rural - urban migration (Y2) by 1 unit, it will increase economic growth. (Y2) of 3.50E-08 units.

2. Government spending (X3) has a positive and significant effect on economic growth (Y2) with a regression coefficient of $1.74 \mathrm{E}-08$. This means that when the increase in government spending (X3) of 1 unit it will be me raise economic growth (Y2) of $1.74 \mathrm{E}-08$ units.

3. Education (X4) has a positive and significant effect on economic growth (Y2) with a regression coefficient of 0.083335 . This means that when there is an increase in education (X4) by 1 unit, it will increase economic growth (Y2) by 0.083335 units.

4. Health (X5) has a positive and significant effect on economic growth (Y2) with a regression coefficient of 0.234740 . This means that when there is an increase in Health (X5) of 1 unit, it will increase economic growth (Y2) by 0.234740 units.

\section{CONCLUSION}

Based on the results of research and discussion of the determinants of rural-urban migration and economic growth between provinces in Indonesia, it can be concluded that. Economic growth has a positive and significant effect on rural-urban migration between provinces in Indonesia. This indicates that economic growth is a determining factor for rural-urban migration between provinces in Indonesia. Indonesia's Provincial Minimum Wage has a positive and significant effect on rural-urban migration between provinces in Indonesia. This condition indicates that the Provincial Minimum Wage is a determining factor for rural-urban migration between provinces in Indonesia. The Labor Force Participation Rate (TPAK) has a positive and significant effect on rural-urban migration between provinces in Indonesia. This indicates that the Labor Force Participation Rate is a determining factor in ruralurban migration between provinces in Indonesia. 
Rural-urban migration has a positive and significant effect on economic growth between provinces in Indonesia. This condition indicates that rural - urban migration is a determining factor for economic growth. Government spending has a positive and significant effect on economic growth between provinces in Indonesia, this situation indicates that government spending is a determining factor for economic growth. Human capital has a positive and significant effect on economic growth between provinces in Indonesia. This condition indicates that human capital is a determining factor for economic growth between provinces in Indonesia.

\section{REFERENCES}

[1] N. G. Mankiw, Makoekonomi, 6th ed. Jakarta: Erlangga, 2007.

[2] M. Afzal, M., Ahmed, SS and Nawaz, "No Title," "Macroeconomic Determ. Urban. Pakistan”, Growth, vol. 5, no. 1, pp. 66-12, 2015, doi: doi: 10.20448 / journal.511.2018.51.6.12.

[3] A. Bankole, "'Urbanization and Economic Growth in West Africa : A Panel Data Approach Urbanization in West Africa and some empirical evidence,"” vol. 17, no. 2, pp. 151-168, 2009.

[4] M. et al. El, "Effects of urbanization on economic growth and human capital formation in Africa," vol. 01068271, 2014.

[5] T. Smith, Development Economics. Jakarta: Erlangga, 2006.

[6] T. T. Tambunan, Indonesian Economy: Theoretical Analysis and Empirical Analysis. Bogor: Ghalia Indonesia, 2011.

[7] S. Solarin, "'The Role of Urbanization in the Economic Development Process: Evidence from Nigeria," vol. 11, no. 3, pp. 223-225, 2017, doi: 10.1177 / 0973801017703512.

[8] K. Tripathi, S. and Mahey, "'Urbanization and economic growth in Punjab (India): an empirical analysis', Urban Research and Practice .

Routledge," vol. 10, no. 4, pp. 379-402, 2017, doi: 10.1080 / 17535069.2016.1227875.

[9] P. Tamang, "'Urbanization and Economic Growth : Investigating Causality Urbanization and Economic Growth : Investigating Causality,” 2017, doi: 10.12966 / e.09.02.2013.

[10] Bandiyono. and indrawardani, "'Overview of Rural-Urban Population Migration, Urbanization and Its Impact," J. Indones. Popul., vol. 5, no. 201, 2010.

[11] L. Bove, V. and Elia, “"Migration, Diversity, and Economic Growth', World Development," vol. 89, pp. 227-239, 2017, doi: 10.1016 / j.worlddev.2016.08.012.

[12] Q. Liu, A., Yao, L. and Li, "“Cointegration Analysis on the Relation between Urbanization and Economic Growth in China," Asian Agric. Res., 2011.

[13] A. Moreno, M. and Hector, "AAuthor Accepted Manuscript', Journal of Development Studie," vol. 17, no. 3, 2011, [Online]. Available: http://www-

wds.worldbank.org/external/default/WDSConte ntServer/WDSP/IB/2013/12/18/000442464_201 31218151209/Rendered/PDF/793790JRN0Natu 00Box0379850B00OUO090.pdf . .

[14] Daniel Yet Fhang Lo, "Urbanization and Economic Growth : Testing for Causality," 16th Annu. Pacific Rim Real Estate Conf. January, pp. 1-25, 2010.

[15] R. Sari, "'The Minimum Wage Policy in Indonesia,” pp. 1-15, 2013, [Online]. Available: http://wartaekonomi.co.id/berita7450/perburuha n-menjaga-keseimbangan-upahdanproduktivitas-bagian-ii.html.

[16] M. Jhingan, Introduction to Economics. Jakarta: Erlangga, 2018.

[17] R. Mala, VSN, Suyadi, B. and Sedyati, "'Analysis of Labor Force Participation Levels Based on the Economic Activities of the Tegalsari Village Community, Tegalsari District, Banyuwangi Regency," J. Econ. Educ. Sci. J. Educ. Econ. Soc. Sci., vol. 1, no. 1, p. 130, 2017, doi: 0.19184 / jpe.v11i1.5014.

[18] A. Anitasari, M. and Soleh, "The Effect of Government Expenditures on Economic Growth in Bengkulu Province," Ekombis Rev., vol. 3, no. 2, pp. 117-127, 2015.

[19] G. Musaba, E., Chilonda, P. and Matchaya, "Impact of Government Sectoral Expenditure on Economic Growth in Malawi, 1980-2007,” pp. 71-79, 2013, doi:

http://www.iiste.org/Journals/index.php/JEDS/a rticle/view/4128.

[20] E. Ogar, A. and Eyo, "Public Expenditure Public Expenditure and Economic Growth in Nigeria : Var Approach," Eur. J. Econ. Financ. Res., pp. 97-105, 2019, doi: 10.5281/ zenodo.3360735.

[21] H. Karaalp-Orhan, "The Impact of GenderSpecific Human Capital on Economic Growth: An Empirical Investigation for Turkey," Zagreb Int. Rev. Econ. Bus., vol. 21, no. 1, pp. 15-30, 2019, doi: 10.2478 / zireb-2018-0021. 
[22] O. Kanayo, "The Impact of Human Capital Formation on Economic Growth in Nigeria," $J$. Econ., vol. 4, no. 2, pp. 121-132, 2013, doi: 10.1080 / 09765239.2013.11884972.

[23] Q. Abbas, "Endogenous growth and human capital: A comparative study of Pakistan and Sri Lanka," Pak. Dev. Rev., vol. 40, no. 4, pp. $987-$ 1007, 2001, doi: 10.30541 / v40i4iipp.987-1007.

[24] A. Rizal, "Contribution of Human and Capital on Regional Economic Growth of Sumedang District of Indonesia," Int. J. Manag. Sci. Bus., vol. 1, no. 1, p. 15, 2019, doi: 10.17509 / msb.v1i1.17109.
[25] S. Dina, R. and Sentosa, "Analysis of Effect of Human Capital, Infrastructure Investment and Infrastructure Consumption of Economic Growth in Indonesia," pp. 124-131, 2019, doi: 10.2991 / piceeba-19.2019.15. 